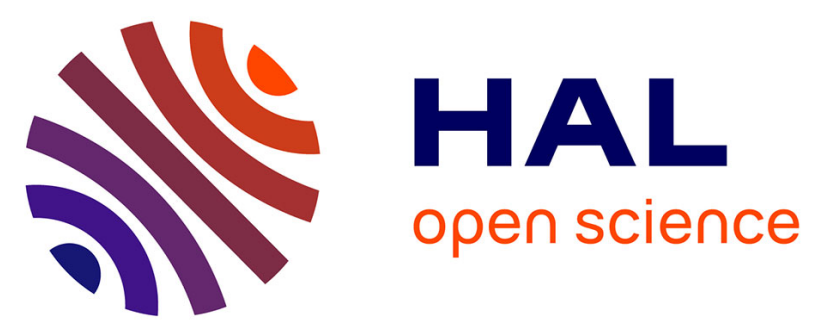

\title{
Relation between microstructure induced by oxidation and room-temperature mechanical properties of the thermally grown oxide scales on austenitic stainless steels
}

Céline Pascal, Muriel Braccini, Valérie Parry, Elena N. Fedorova, Marc

Mantel, Djar Oquab, Daniel Monceau

\section{To cite this version:}

Céline Pascal, Muriel Braccini, Valérie Parry, Elena N. Fedorova, Marc Mantel, et al.. Relation between microstructure induced by oxidation and room-temperature mechanical properties of the thermally grown oxide scales on austenitic stainless steels. Materials Characterization, 2017, 127, pp.161-170. 10.1016/j.matchar.2017.03.003 . hal-01578676

\section{HAL Id: hal-01578676 \\ https://hal.science/hal-01578676}

Submitted on 29 Aug 2017

HAL is a multi-disciplinary open access archive for the deposit and dissemination of scientific research documents, whether they are published or not. The documents may come from teaching and research institutions in France or abroad, or from public or private research centers.
L'archive ouverte pluridisciplinaire HAL, est destinée au dépôt et à la diffusion de documents scientifiques de niveau recherche, publiés ou non, émanant des établissements d'enseignement et de recherche français ou étrangers, des laboratoires publics ou privés. 


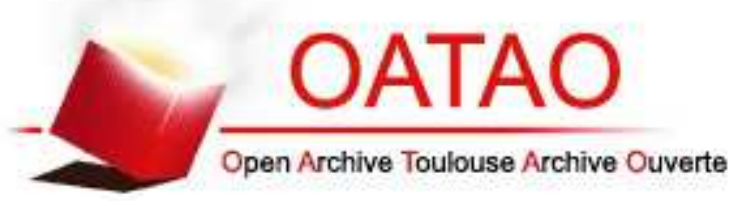

\section{Open Archive TOULOUSE Archive Ouverte (OATAO)}

OATAO is an open access repository that collects the work of Toulouse researchers and makes it freely available over the web where possible.

This is an author-deposited version published in : http://oatao.univ-toulouse.fr/ Eprints ID : 18109

To link to this article: DOI: $10.1016 /$ j.matchar.2017.03.003

URL: http://dx.doi.org/10.1016/j.matchar.2017.03.003

To cite this version: Pascal, Céline and Braccini, Muriel and Parry, Valérie and Fedorova, Elena N. and Mantel, Marc and Oquab, Djar and Monceau, Daniel Relation between microstructure induced by oxidation and room-temperature mechanical properties of the thermally grown oxide scales on austenitic stainless steels. (2017) Materials Characterization, vol. 127. pp. 161-170. ISSN 1044-5803

Any correspondence concerning this service should be sent to the repository administrator: staff-oatao@ listes-diff.inp-toulouse.fr 


\title{
Relation between microstructure induced by oxidation and room-temperature mechanical properties of the thermally grown oxide scales on austenitic stainless steels
}

\author{
Céline Pascal ${ }^{\mathrm{a}, *}$, Muriel Braccini ${ }^{\mathrm{a}}$, Valérie Parry ${ }^{\mathrm{a}}$, Elena Fedorova ${ }^{\mathrm{b}, \mathrm{c}}$, Marc Mantel ${ }^{\mathrm{a}, \mathrm{d}}$, \\ Djar Oquab $^{\mathrm{e}}$, Daniel Monceau ${ }^{\mathrm{e}}$ \\ a Univ. Grenoble Alpes, CNRS, Grenoble INP ${ }^{1}$, SIMaP, F-38000 Grenoble, France \\ b Siberian Federal University, Krasnoyarsk, Russia \\ ' Institute of Computational Technologies SB RAS, SKTB Nauka, 660049 Krasnoyarsk, Russia \\ d UGITECH SA, Ugine, France \\ e Université de Toulouse, Institut Carnot CIRIMAT, ENSIACET, France
}

Keywords:

Austenitic stainless steel

Resulphurized steel

High temperature oxidation

Tensile testing

Microstructure

\begin{abstract}
A B S T R A C T
The spalling/cracking behaviour, at room temperature, of thermally grown oxide scales under tensile stress was investigated using SEM in-situ tensile testing for two austenitic stainless steels with close composition except their S content. A correlation between damage patterns, microstructure, mechanical and adhesion properties of the oxide scales is proposed. The difference in microstructure evolution during oxidation between the two steels is explained in relation with the volume fraction of MnS inclusions in the substrate (i.e. S content). Although a direct effect of $\mathrm{S}$ content on the oxide scale adhesion is not evidenced, the metal/oxide toughness seems strongly affected by oxides features such as scale thickness, Fe content and location of internal oxides $\left(\mathrm{SiO}_{2}\right.$ along the metal/scale interface or at the grain boundaries of the underneath substrate).
\end{abstract}

\section{Introduction}

Austenitic stainless steels are widely used corrosion resistant materials associating toughness and weldability. The two major alloying elements of austenitic stainless steels are nickel, which allows the steel to remain austenitic and to have the fcc-lattice ductility, and chromium which is responsible for high temperature corrosion resistance. These steels resist to rapid oxidation by the selective consumption of chromium which form a slow growing chromia scale $\left(\mathrm{Cr}_{2} \mathrm{O}_{3}\right)$. Chromia forms a protective scale which hinders further oxidation thanks to its very low diffusion coefficients for oxygen and metals [1]. Investigations related to chromia-forming alloys containing $\mathrm{Mn}$ report the formation of a to two-layered oxide scale composed of a dense and adherent inner sublayer of chromia $\left(\mathrm{Cr}_{2} \mathrm{O}_{3}\right)$ and an outer sublayer of $\mathrm{MnCr}_{2} \mathrm{O}_{4}$ spinel type oxide [2-6]. Besides the minimum bulk concentration of $\mathrm{Cr}$ required to form a continuous chromia scale, adhesion and mechanical

\footnotetext{
* Corresponding author at: Laboratoire SIMaP, 1130 Rue de la Piscine, BP75, 38402 Saint Martin d'Hères, France.

E-mail addresses: celine.pascal@simap.grenoble-inp.fr (C. Pascal),

muriel.braccini@simap.grenoble-inp.fr (M. Braccini), valerie.parry@simap.grenoble-inp.fr (V. Parry), efedorova@sfu-kras.ru (E. Fedorova), marc.mantel@ugitech.com (M. Mantel), djar.oquab@ensiacet.fr (D. Oquab), daniel.monceau@ensiacet.fr (D. Monceau).

${ }^{1}$ Institute of Engineering Univ. Grenoble Alpes.
}

resistance of oxide scale are key parameters for oxidation resistance of chromia-forming austenitic stainless steels.

Minor elements, such as Si, Mn, C, N and S, are added to improve steels properties but may be detrimental to their corrosion resistance. Sulphur is added to improve machinability of stainless steels. The content of manganese is then increased in resulphurized steels to favour the formation of MnS inclusions at the expense of non-deformable FeS inclusions. Nevertheless, sulphur is also linked to deleterious effects on adhesion of thermally grown alumina $\left(\mathrm{Al}_{2} \mathrm{O}_{3}\right)$ and chromia $\left(\mathrm{Cr}_{2} \mathrm{O}_{3}\right)$ scales during isothermal or cyclic oxidation experiments performed on alumina-forming or chromia-forming alloys respectively [7-17].

In-situ tensile testing at room temperature is commonly used to study mechanical resistance of brittle coating on ductile substrate [18-21]. If this method gains a new interest with investigations of thin film on flexible substrate, it has been formerly used to study thermally grown oxide scale [22-24]. This method consists in the observation of the oxide scale surface (with optical method or in a scanning electron microscope) while deforming the oxidized metal using a uniaxial tensile device.

After cooling to room temperature, thermally grown oxide scales are usually in a compressive stress state due (i) to mainly "thermal stresses" originated from mismatch of thermal expansion coefficients of oxide scale and metallic substrate and generated during cooling from the oxidation temperature and (ii) to oxides "growth stresses" related to 
strain in the oxide scale that builds up during its growth at oxidation temperature. During tensile testing, these residual compressive stresses are firstly relieved in the loading direction before tensile stress is actually generated in the oxide scale. Whereas tensile stress builds up in the loading direction, compressive stress is also generated in the perpendicular direction. In direction perpendicular to the tensile loading, the metal substrate contracts: first, because of Poisson's effect in the elastic domain, then due to volume conservation in the plastic domain. Because of the difference in mechanical behaviour between the oxide and the metal, this contraction results in a compressive stress in the oxide scale. Even if the level of this compressive stress is low compare to the ones generated during the oxidation process and the cooling to room temperature, it adds up to those residual stresses and allows reaching critical value for damage initiation and growth. Thus, even if after the oxidation thermal cycle residual stresses did not lead to damages in the oxide scale, the uniaxial tensile deformation brings just enough extra stress to initiate damages. Various damage patterns can then be observed at the surface of the oxide scale: not only cracking due to tensile stress but also spalling.

Spallation may occur according to different mechanisms similar to those due to residual stresses during oxidation thermal cycle [25]:

(i) If the tensile stress in the loading direction leads to failure of the oxide scale by through-thickness cracks, then stress redistribution results in shear stress at the metal/oxide interface at crack edge $[25,26]$. This shear stress may lead to crack deviation to the metal/oxide interface [27].

(ii) Compressive stress in the direction perpendicular to the loading direction may also lead to spallation according to two mechanisms depending on the relative toughness of the oxide compare to the metal/oxide toughness: wedging or buckling [25]. If the oxide is weak and the interface strong, the oxide will first fail under shear-compression stress and then, as compressive stress increases, the wedges of the crack forming a $45^{\circ}$ angle will slide on one another and lead to a gradual decohesion of the interface. If the oxide is strong and the interface is weak, the interface will delaminate first, allowing the oxide to buckle, then, because of the tensile stress generated by the buckling, the oxide will fail.

This is why various damage scenarii are observed during tensile testing of brittle coating on ductile substrate. Most often, authors report transverse cracks in the coating with an increasing density of cracks until reaching a saturation value when spallation takes place [19] Sometimes saturation is reached without any spallation: in this case saturation is due to localized deformation in the ductile substrate preventing stress transfer to the coating $[21,28]$.

In this paper, the spallation/cracking behaviour of thermally grown oxide scales under tensile stress was investigated for two austenitic stainless steels with close composition except their S content: AISI 304L (250 wppm S) and AISI 303 (2950 wppm S). Surfaces of oxide scale thermally grown on specimens were observed using scanning electron microscope (SEM) during tensile testing performed at room temperature. Cross-sections of oxide scale before and after tensile testing were observed using SEM to understand the scenario of oxide scale damages.

\section{Materials and Methods}

Austenitic stainless steels, AISI 304L and AISI 303, provided by Ugitech France, were produced by continuous casting, hot rolling and cold drawing. Their chemical compositions are reported in Table 1.

For as-received AISI 304L and AISI 303, the mean grain size is around 25-30 $\mu \mathrm{m}$ (Fig. 1). MnS inclusions, appearing as black and thin filaments in Fig. 1, can be observed in a greater amount in AISI 303 since the sulphur content in this alloy is ten times higher than in AISI 304L (Table 1). These MnS inclusions, highly deformable at the temperature of the
Table 1

Chemical compositions of austenitic stainless steels AISI 304L and AISI 303 (from fluorescence spectroscopy analysis and optical emission spectrometry equipped with a gas analyzer).

\begin{tabular}{lllllllllll}
\hline [wt\%] & $\mathrm{Fe}$ & $\mathrm{Ni}$ & $\mathrm{Cr}$ & $\mathrm{Mn}$ & $\mathrm{Si}$ & $\mathrm{C}$ & $\mathrm{S}$ & $\mathrm{N}$ & $\mathrm{O}$ & $\mathrm{Ca}$ \\
\hline AISI 304L & Bal. & 8.960 & 18.040 & 1.128 & 0.458 & 0.021 & 0.025 & 0.048 & 0.010 & 0.005 \\
AISI 303 & Bal. & 8.284 & 17.100 & 1.746 & 0.443 & 0.055 & 0.295 & 0.035 & 0.015 & 0.013 \\
\hline
\end{tabular}

rolling process, are oriented in the working direction of the bar. Elongated residual $\delta$-ferrite, appearing in grey in Fig. 1 , is related to an incomplete transformation into $\gamma$-austenite during solidification. The amount of residual $\delta$-ferrite is higher for AISI $304 \mathrm{~L}(\sim 2 \%)$ than for AISI $303(\sim 1 \%)$ as a direct consequence of the chemical composition of the two grades.

Tensile specimens were cut in longitudinal cold drawing direction by electrical discharge machining. The gauge section was $2 \mathrm{~mm}$ width by $1 \mathrm{~mm}$ thick and the gauge length was $3 \mathrm{~mm}$ (labelled 1 in Fig. 2). Before oxidation experiments, the specimens were ground with $\mathrm{SiC}$ paper up to P1200 grade and cleaned in an ultrasonic bath with acetone then high-purity alcohol.

Tensile specimens were oxidized in a tubular furnace set at either 700,900 or $100{ }^{\circ} \mathrm{C}$ in air or $\mathrm{O}_{2}$ flow for $50 \mathrm{~h}$ or $70 \mathrm{~h}$. Tensile specimens, previously oxidized, were inserted in a micromechanical device adapted into a scanning electron microscope (SEM, JEOL JSM 6400) as shown in Fig. 2. This device allows the continuous observation at a microscopic scale of the damage mechanisms in the oxide layer. The straining system induces a symmetrical displacement of the grips (labelled 3 in Fig. 2) and the observation of the sample surface does not require refocusing and recovery of the observation area. A displacement rate of $50 \mu \mathrm{m} \cdot \mathrm{min}^{-1}$ was chosen during tensile testing performed at room temperature. During a tensile test, the uniform central part of the sample was carefully observed. Image magnification was set to $\times 200$ in the present study, in SE or BSE mode. The symmetrical displacement motion was interrupted in order to acquire images of the oxide scale surface for given strain $(\varepsilon)$ or when damages occur such as oxide scale transverse cracking or spallation. The strain related to such damages is approximate since it only corresponds to visible events in a limited observed area. The tensile testing was stopped after extensive damages occurrence and consequently before specimen fracture point. Sequential micrographs of the damage evolution in the oxide scale have been
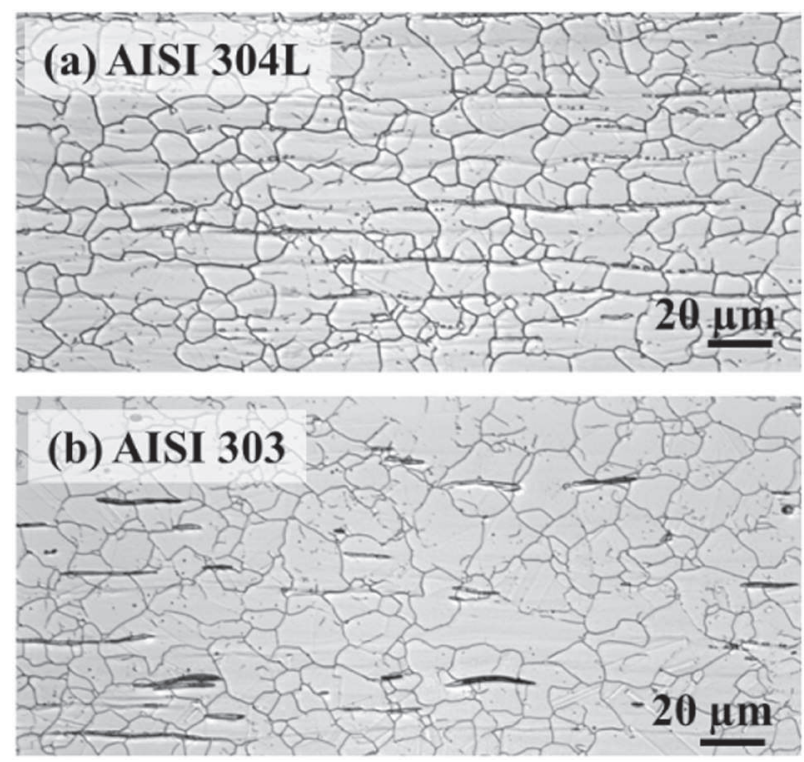

Fig. 1. Optical micrographs of (a) AISI 304L and (b) AISI 303 substrates after electrolytic etching in $85 \%$ nitric acid revealing the grain boundaries, the elongated residual $\delta$-ferrite and MnS sulphides. 


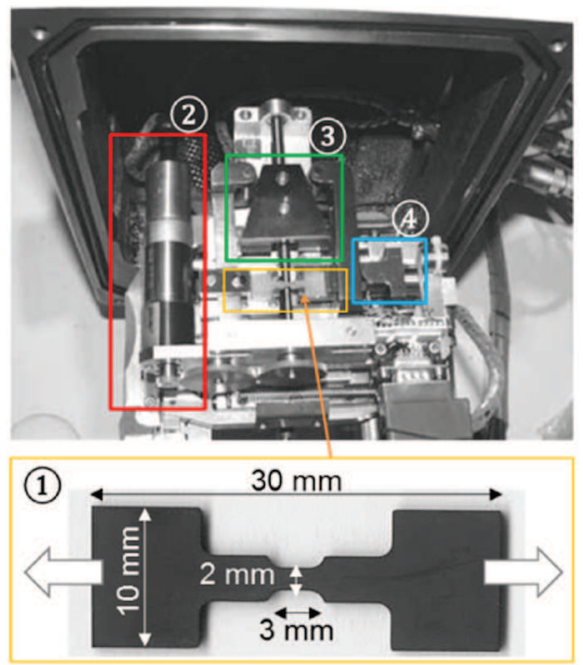

(1) Specimen

(2) Motorization

(3) Symmetric loading of the specimen

(4) Numerical measurement of load (max. $250 \mathrm{daN}$ ) and displacement

Fig. 2. Micromechanical device adapted into a scanning electron microscope and shape of oxidized tensile specimen.

collected according to the applied strain which is calculated from recorded elongation values during tensile testing. These elongation values were higher than those of the observed central part of the sample, comprising many other deformations, like elongation of the specimen holder or bending of the transmission arms. The actual strain at sample centre was therefore calculated for each stress by subtracting the tensile rig compliance. To do so, the rig compliance is estimated in the linear elastic domain of the specimen assuming a known Young's modulus (200 GPa for steels). This correction was applied without taking into account the presence of the thin oxide scale which contribution to the mechanical properties of the specimens can be neglected. Then, the stress-strain curve can be plotted allowing determination of mechanical properties of the substrate.

Oxide scales cross-sections were observed before and after SEM in situ tensile testing. The samples' surface was coated with epoxy resin to prevent oxide scale damages during metallographic preparation (cutting, grinding and polishing). The cross-sections were ground up to 1200 grit SiC paper and polished up to $1 \mu \mathrm{m}$ diamond paste. The SEM micrographs and EDX maps of the cross-sections were performed using a FEG-SEM Zeiss Ultra 55 equipped with a SSD Bruker X-ray detector.

\section{Results and Discussion}

\subsection{Mechanical Properties of the Substrate After Oxidation}

Mechanical properties of the substrate after oxidation can be determined from the stress-strain curves achieved during SEM in situ tensile testing since the oxide thickness is negligible beside the substrate one. The two steels exhibit similar mechanical behaviour after oxidation (Fig. 3).

Steps observed on the stress-strain curves correspond to load relaxation during tensile testing interruptions to acquire images of the oxide top surface. For both alloys, after oxidation at $700{ }^{\circ} \mathrm{C}$, a higher yield strength resulting from strain hardening during steel drawing processes is evidenced.

After oxidation at $900{ }^{\circ} \mathrm{C}$ or $1000^{\circ} \mathrm{C}$, typical mechanical properties of AISI 304L and AISI 303 (yield strength of $240 \mathrm{MPa}$ and $310 \mathrm{MPa}$ respectively and tensile strength of 585 MPA and 620 MPa respectively [29]) are restored since oxidation thermal treatment also acts as a recovery/ recrystallization annealing.

The softening evidenced on strain-stress curves is corroborated by micro-hardness measurements. For instance, the hardness of AISI $304 \mathrm{~L}$ substrate decreases from $215 \pm 10 \mathrm{HV}_{0.5}$ to $140 \pm 5 \mathrm{HV}_{0.5}$ when oxidation temperature increases from $700^{\circ} \mathrm{C}$ to $1000^{\circ} \mathrm{C}$. For both steel grades, the hardness values are in good agreement with the yield strength deduced from the stress-strain curves.

The mechanical properties evolution is consistent with grain size evolution. After oxidation at $900{ }^{\circ} \mathrm{C}$ and $1000{ }^{\circ} \mathrm{C}$, a significant grain growth is observed in relation with the metal softening as shown in Fig. 4.
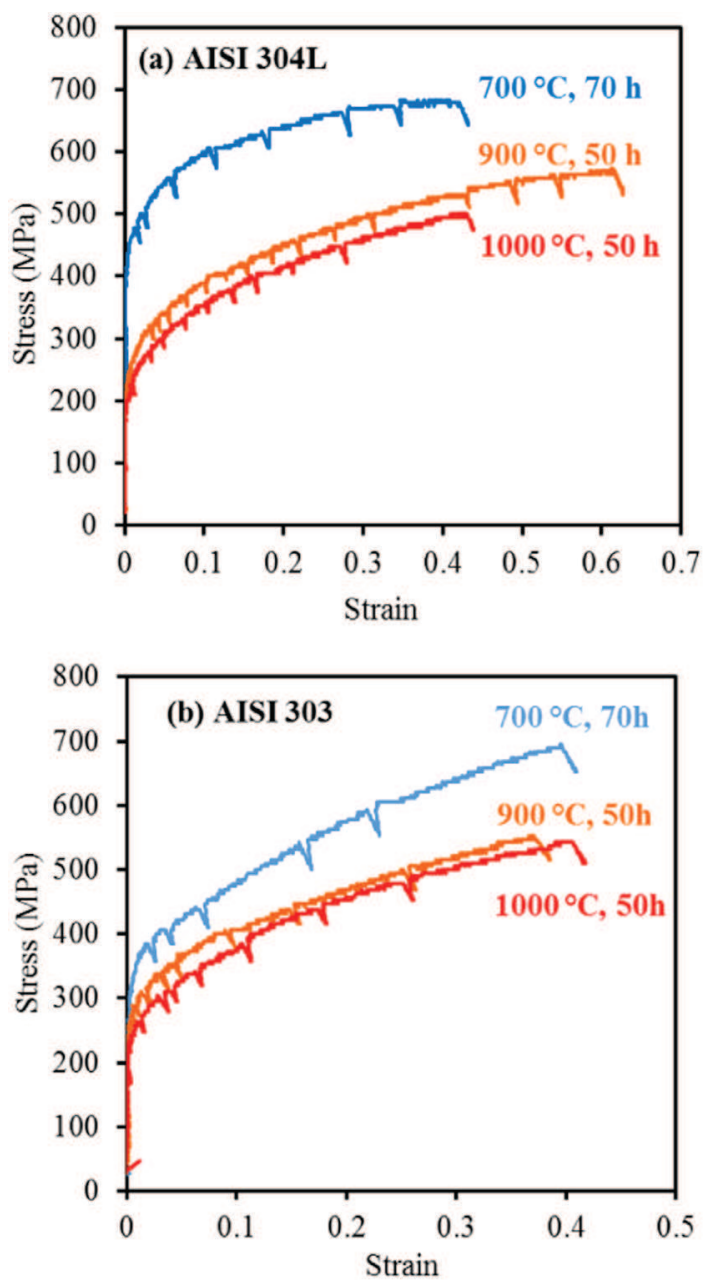

Fig. 3. Stress-strain curves of (a) AISI $304 \mathrm{~L}$ and (b) AISI 303 after oxidation at $700{ }^{\circ} \mathrm{C}$ for $70 \mathrm{~h}$, at $900{ }^{\circ} \mathrm{C}$ for $50 \mathrm{~h}$ and $1000{ }^{\circ} \mathrm{C}$ for $50 \mathrm{~h}$. 


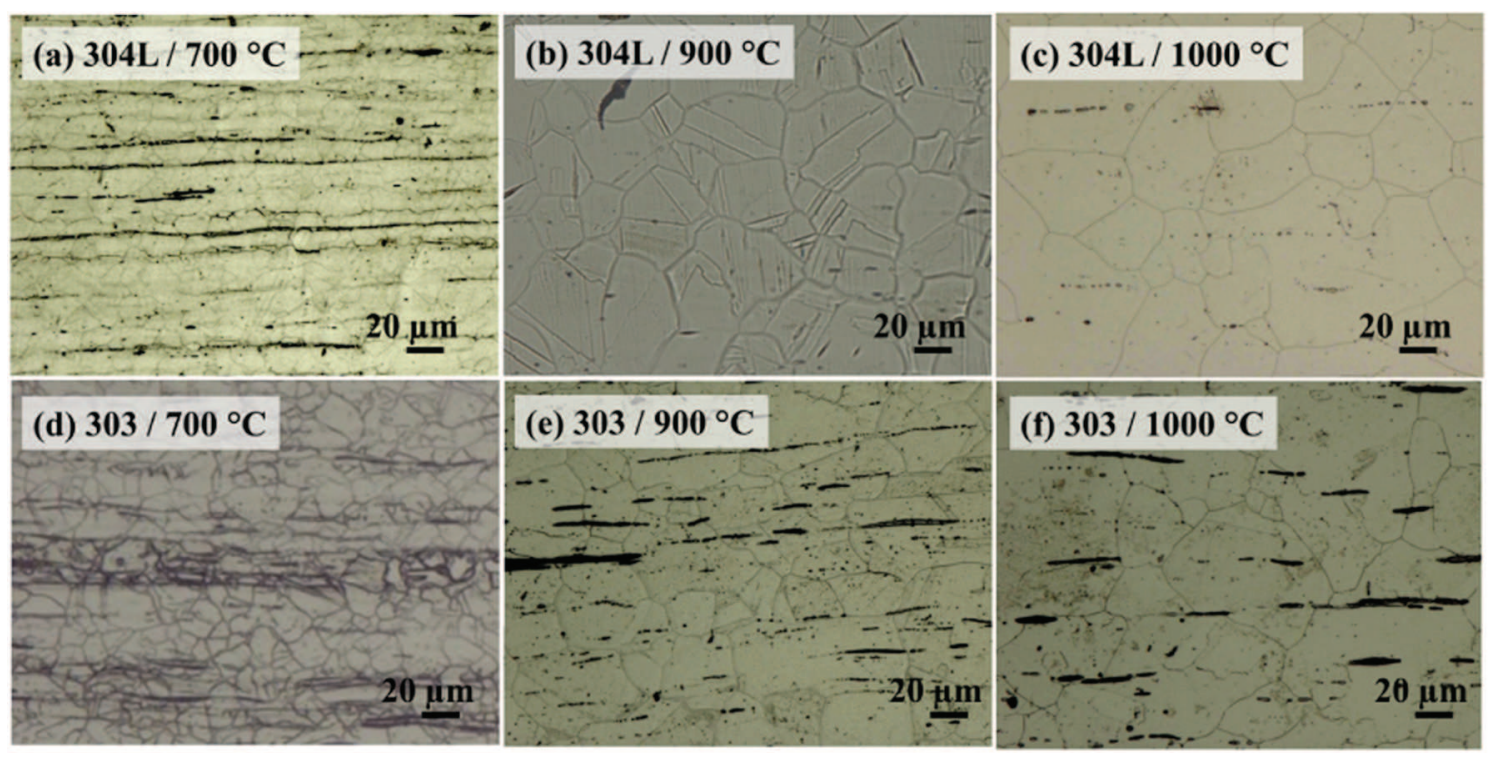

Fig. 4. Optical micrographs of AISI $304 \mathrm{~L}$ substrates after oxidation at (a) $700^{\circ} \mathrm{C}$, (b) $900{ }^{\circ} \mathrm{C}$ and (c) $1000^{\circ} \mathrm{C}$ and of AISI 303 substrates after oxidation at (d) $700{ }^{\circ} \mathrm{C}$, (e) $900{ }^{\circ} \mathrm{C}$ and (f) $1000^{\circ} \mathrm{C}$ (after electrolytic etching in $85 \%$ nitric acid to reveal the elongated black MnS sulphides and the grain boundaries).

According to the mechanical properties of the substrate after oxidation, the oxide scale spalling is expected to be favoured after oxidation at $700{ }^{\circ} \mathrm{C}$ because the substrate, with higher yield strength, has a lower stress relaxation capacity which could result in a better stress transfer to the oxide scale.

\subsection{Damages in the Oxide Scales Previously Grown at $700{ }^{\circ} \mathrm{C}$}

The sequential micrographs obtained during tensile testing of the specimens oxidized at $700{ }^{\circ} \mathrm{C}$ for $70 \mathrm{~h}$ are reported in Fig. 5. For the oxide thermally grown on AISI 304L, first spalls appear for strain about 5\% (Fig. 5a). In the present study, the SEM magnification during tensile testing, $\times 200$, is suitable to observe a large oxide scale area but the first thin spalls (or cracks) are hardly visible. Therefore, this critical strain is overestimated.
At the end of the tensile testing, for a strain about $21 \%$, only moderate spalling is observed without visible cracks (Fig. 5b). For the resulphurized steel, AISI 303, nearly the same behaviour is observed except the formation of localized cracks area for strain above $16 \%$ (arrow in Fig. 5d). For higher strain, the opening of these cracks is observed without any propagation (Fig. 5e). The formation of these localized cracks could be related to oxide scale locally enriched in Fe. EDS analysis (not presented) confirms that oxide scale at the vicinity of cracks is rich in $\mathrm{Cr}$, as for the sound oxide scale, but contains a higher Fe content. This higher Fe content could be characteristic of a thicker oxide scale with more defects leading to a locally less resistant oxide scale. These observations indicate that the oxide scale grown on AISI $304 \mathrm{~L}$ is slightly more resistant and adherent.

For both steel grades, at the end of the tensile testing, the spallation remains limited even if the high yield strength of the substrate favours stress transfer to the oxide scale. Nevertheless, top surface and cross-
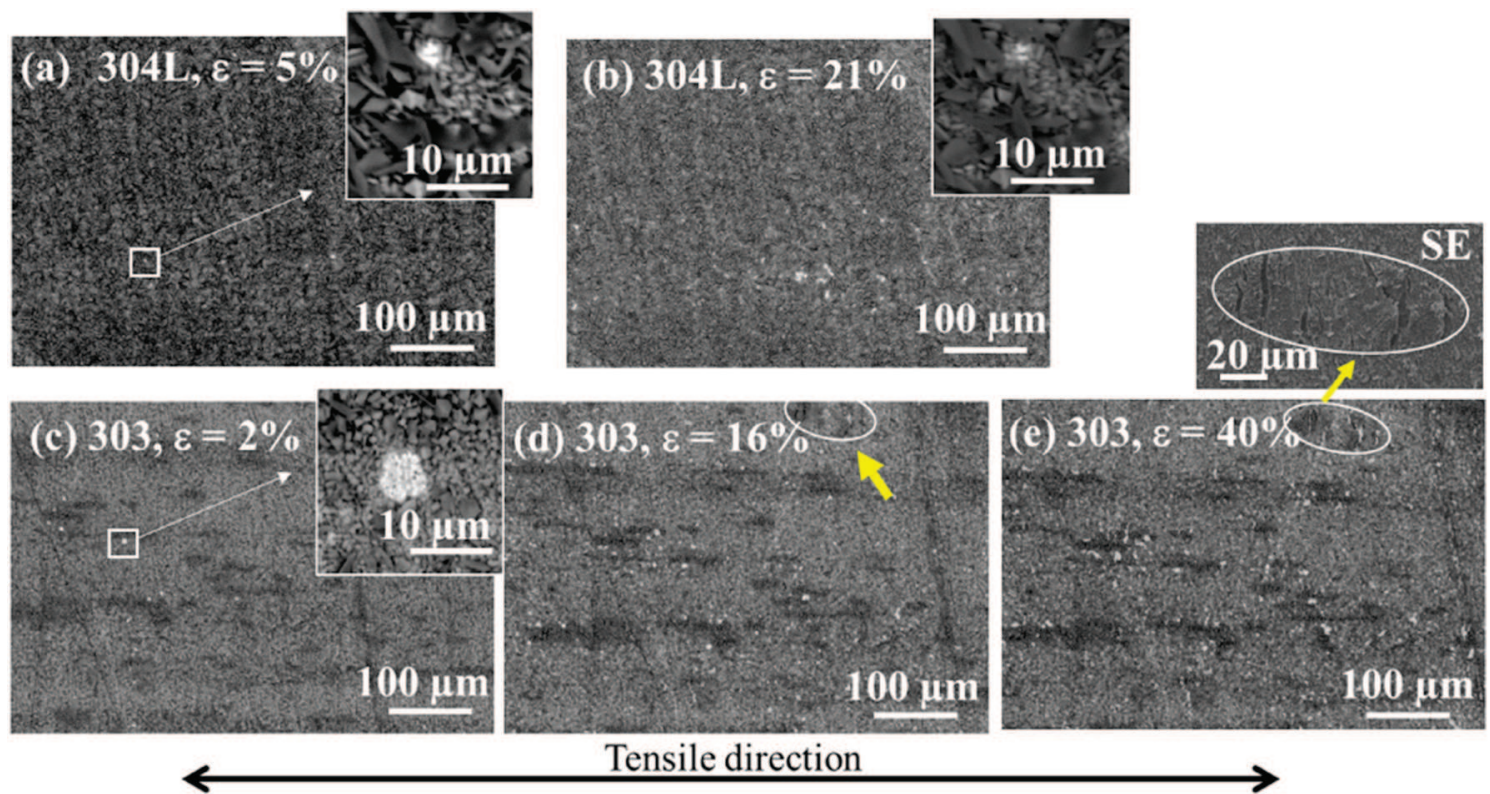

Fig. 5. The sequential SEM-BSE micrographs of the oxide top surface during tensile testing of (a-b) the AISI $304 \mathrm{~L}$ specimen oxidized at $700{ }^{\circ} \mathrm{C}$ for $70 \mathrm{~h}$ and (c-e) the AISI 303 specimen oxidized at $700{ }^{\circ} \mathrm{C}$ for $70 \mathrm{~h}$ (b and e correspond to the end of the test for AISI 304L and AISI 303 substrates respectively). 

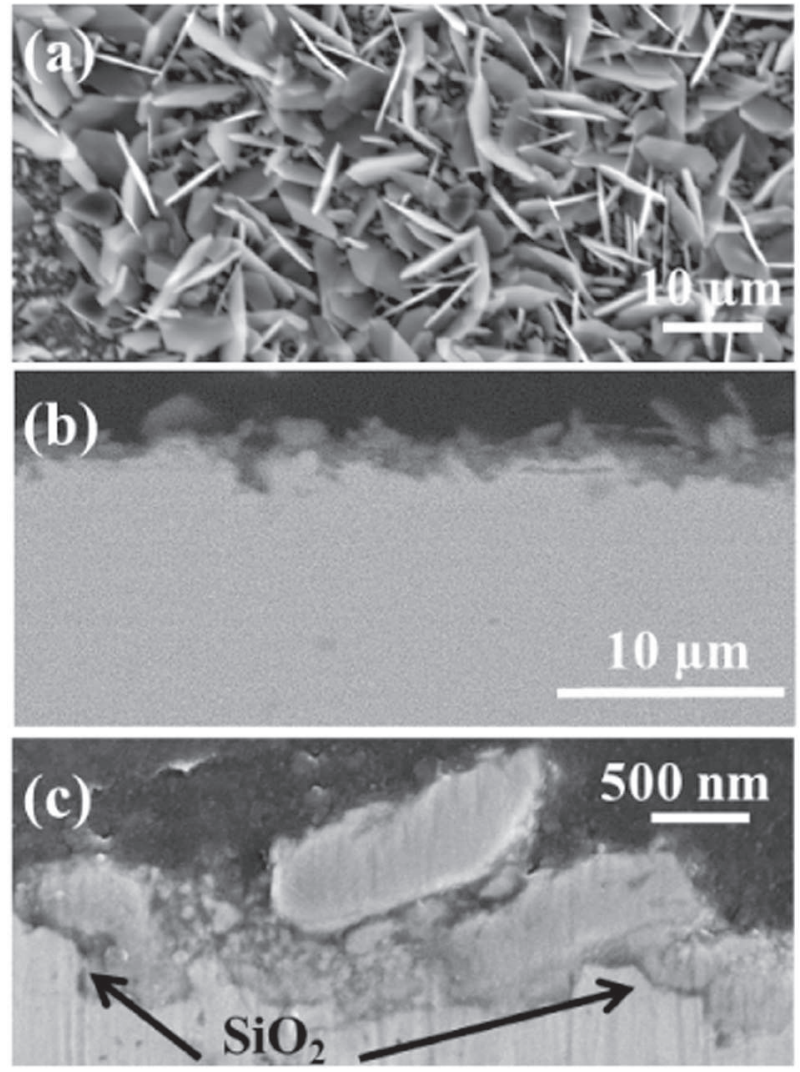

Fig. 6. (a) Surface SEM-SE micrograph and (b), (c) SEM-BSE cross-section micrographs of the oxide scale grown on AISI $304 \mathrm{~L}$ after oxidation at $700{ }^{\circ} \mathrm{C}$ for $70 \mathrm{~h}$. section micrographs before tensile testing in Fig. $6 a$ and $b$ reveal that the oxide scale is thin $(\sim 500 \mathrm{~nm})$ and as a consequence resistant

The oxide scale is composed of a corundum-type oxide $(\mathrm{Cr}, \mathrm{Fe})_{2} \mathrm{O}_{3}$ with a discontinuous silica subscale (arrows in Fig. 6c). During tensile testing, compressive stress is generated in the oxide scale in the direction perpendicular to the tensile direction. This compressive stress is due to contraction of the metal substrate in the directions perpendicular to the tensile direction (Poisson's effect during the elastic deformation, volume conservation in the plastic domain). Then, the difference in mechanical behaviour between the oxide and the metallic substrate results in the development of compressive stress in the oxide scale. In area where the scale adhesion is weakened, compressive stress leads to interface decohesion and scale spallation. The most probable mechanism for this spallation is the "buckling mechanism" as described by Evans [25]. Indeed, on one hand, the oxide toughness appears to be strong since no cracks are observed on the oxide surface. On the other hand, silica interlayer may locally weaken the metal/oxide interface $[28,30]$. Thus, compressive stress will initiate buckling of the oxide scale over area weakened by silica interlayer, then through-thickness cracks form in the oxide due to tensile stress generated by this buckling.

\subsection{Damages in the Oxide Scales Previously Grown at $900{ }^{\circ} \mathrm{C}$}

The sequential micrographs obtained during tensile testing of the specimens oxidized at $900{ }^{\circ} \mathrm{C}$ for $50 \mathrm{~h}$ are reported in Fig. 7. The first cracks appear for nearly the same critical strain 2-3\% for both steels (Fig. 7a and e) and present a wavy shape (Fig. 7c and g). For the oxide scale grown on the resulphurized steel, AISI 303, few spalls are also observed in Fig. 7f between two cracks due to compressive stresses developed in the direction perpendicular to the tensile axis.

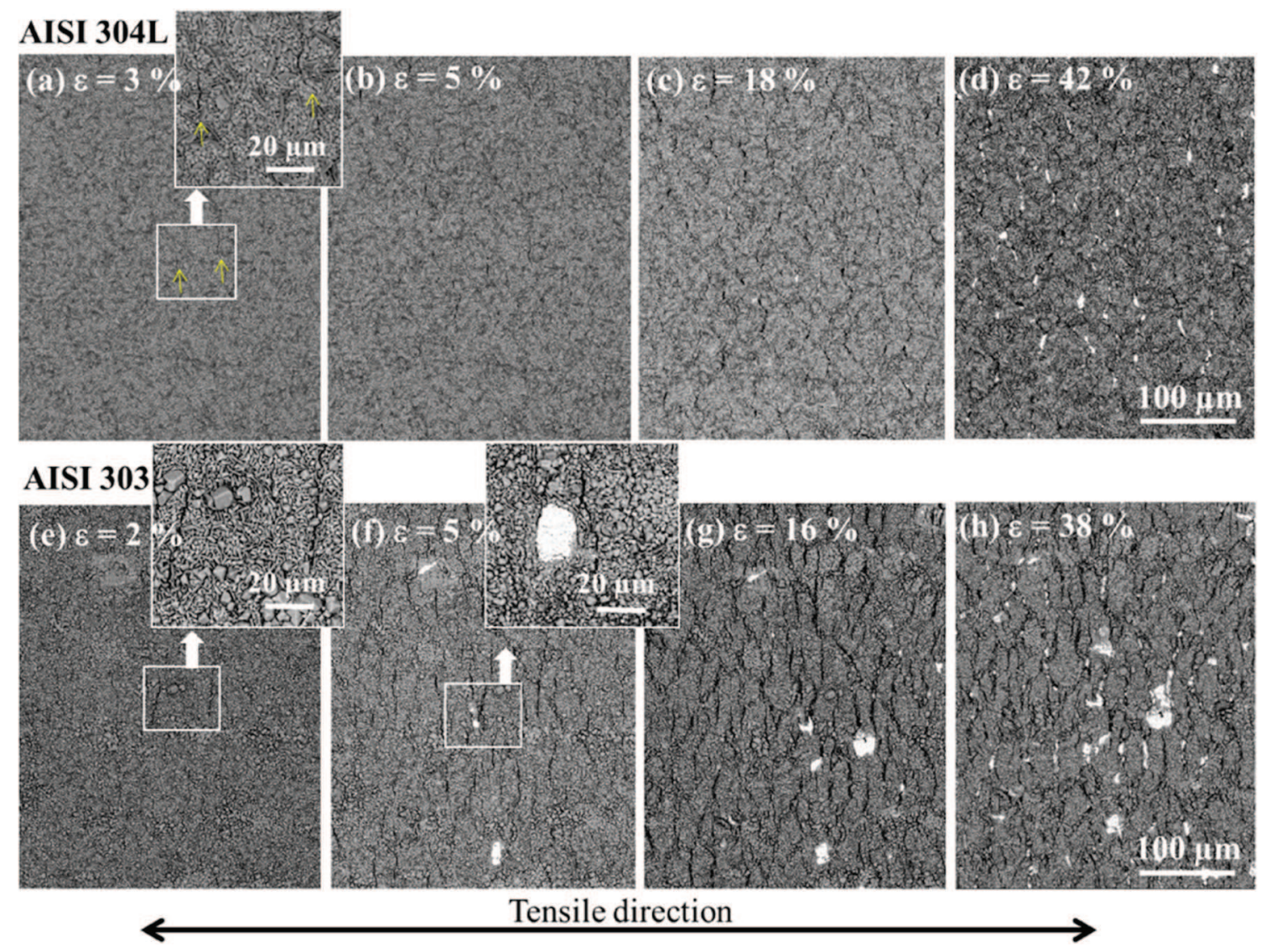

Fig. 7. The sequential SEM-BSE micrographs of the oxide top surface during tensile testing of (a-d) the AISI $304 \mathrm{~L}$ specimen oxidized at $900{ }^{\circ} \mathrm{C}$ for $50 \mathrm{~h}$ and (e-h) the AISI 303 specimen oxidized at $900{ }^{\circ} \mathrm{C}$ for $50 \mathrm{~h} \mathrm{(d}$ and h correspond to the end of the test for AISI 304L and AISI 303 substrates respectively). 

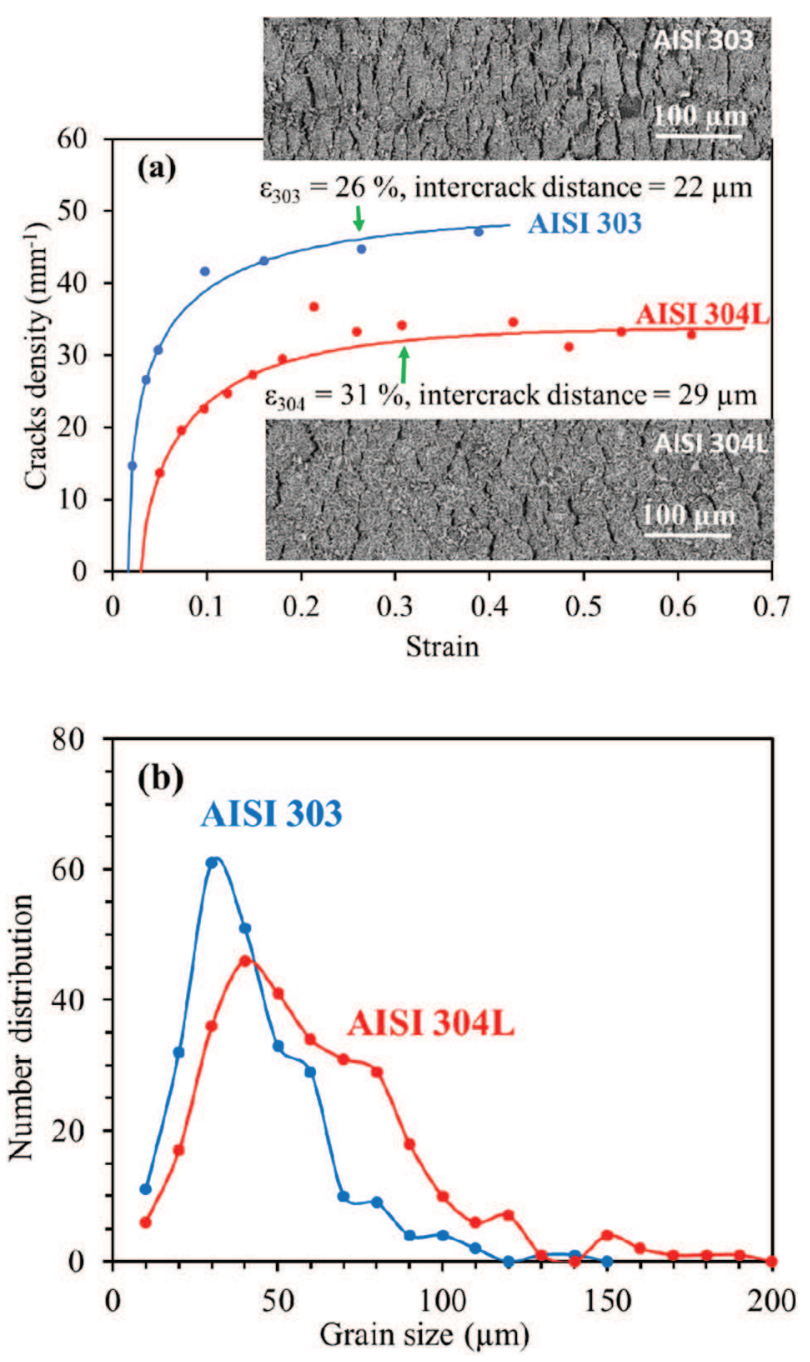

Fig. 8. (a) Cracks density versus strain measured on sequential micrographs obtained during tensile testing of a sample oxidized at $900{ }^{\circ} \mathrm{C}$ for $50 \mathrm{~h}$ and (b) Grain size distribution in number for both substrates.

Usually straight cracks are expected to be formed perpendicularly to the tensile direction. In this case, wavy-shaped cracks are observed and seem to follow the grain boundaries of the underneath substrate. In order to verify this assumption, the cracks density using the intercept method is determined and intercrack distances are compared to the grain size of the underneath substrate. The cracks density as function of applied strain during tensile testing is plotted in Fig. 8a. Similar cracking behaviour is observed for the two austenitic stainless steels with the same following steps: crack initiation, increase of cracks density, saturation (i.e. increase of strain without additional cracks) and finally cracks widening.

For AISI 303, a more severe cracking behaviour is evidenced: crack density increases faster and the saturation value is higher, i.e. $48 \mathrm{~mm}^{-1}$ instead of $34 \mathrm{~mm}^{-1}$. Intercrack distances at saturation are about $\sim 20 \mu \mathrm{m}$ for AISI 303 and $~ 30 \mu \mathrm{m}$ for AISI 304L.

The grain size distributions (in number) are presented in Fig. 8b. The grain size distribution of AISI 303 is narrower and centred around $30 \mu \mathrm{m}$ while the AISI $304 \mathrm{~L}$ one is wider and shifts to higher grain size $(40-50 \mu \mathrm{m})$. The wide grain size distribution observed for AISI 304L could result from discontinuous grain growth, also known as abnormal grain growth or secondary recrystallization [31,32]. In AISI 303, the dispersion of MnS inclusions may slow down recrystallization by grain boundaries pinning and delay subsequent grain growth. Even if the intercrack distance and grain size are both lower for AISI 303 compared to AISI 304L, a relation between cracks location and grain boundaries of the underneath substrate cannot be clearly established from these results.

The cross-sections after tensile testing, presented in Fig. 9, reveal the typical microstructure of protective oxide scale on austenitic stainless steels [2-6]. The oxide scale is composed of two subscales: external spinel-type oxide $\mathrm{MnCr}_{2} \mathrm{O}_{4}$ (orange area of EDS maps in Fig. 9) and internal chromia $\mathrm{Cr}_{2} \mathrm{O}_{3}$ with small amount of $\mathrm{Fe}$ in solid solution (green area of EDS maps in Fig. 9) underlined by silica $\mathrm{SiO}_{2}$ (yellow area of EDS maps in Fig. 9).

The successive oxides, $\mathrm{MnCr}_{2} \mathrm{O}_{4} / \mathrm{Cr}_{2} \mathrm{O}_{3} / \mathrm{SiO}_{2}$, are consistent with thermodynamic considerations. During the initial stage of oxidation, chromia is formed. Once $\mathrm{Cr}_{2} \mathrm{O}_{3}$ is formed, the oxygen partial pressure at the metal/oxide interface strongly decreases. Oxygen partial pressure is then controlled by the decomposition pressure of $\mathrm{Cr}_{2} \mathrm{O}_{3}$ which is very low. Elements such as $\mathrm{Si}$ and $\mathrm{Mn}$, forming more stable oxides, can be oxidized selectively in the vicinity of $\mathrm{Cr}_{2} \mathrm{O}_{3}$ oxide to form $\mathrm{SiO}_{2}$ and $\mathrm{MnO}$ respectively. Depending on the activity and diffusion coefficient of these elements in metal, and also depending on the solubility and diffusion of oxygen, these oxides can precipitate internally or form an underlying layer at the metal/scale interface. In fact, $\mathrm{MnO}$ is not observed because manganese diffuses rapidly in the oxide scale and $\mathrm{MnCr}_{2} \mathrm{O}_{4}$ nucleates from the pre-existing $\mathrm{Cr}_{2} \mathrm{O}_{3}$ at the outer scale part [33].

The low diffusion coefficient of oxygen in fcc-austenite lattice, compared to the grain boundary diffusion coefficient, results in silica internal oxidation along the steel grain boundaries (i.e. intergranular formation of silica, perpendicularly to the metal/oxide interface) as already observed in literature $[16,22,28,34-36]$. This internal silica seems to play a key role in the damage behaviour of the system. First,
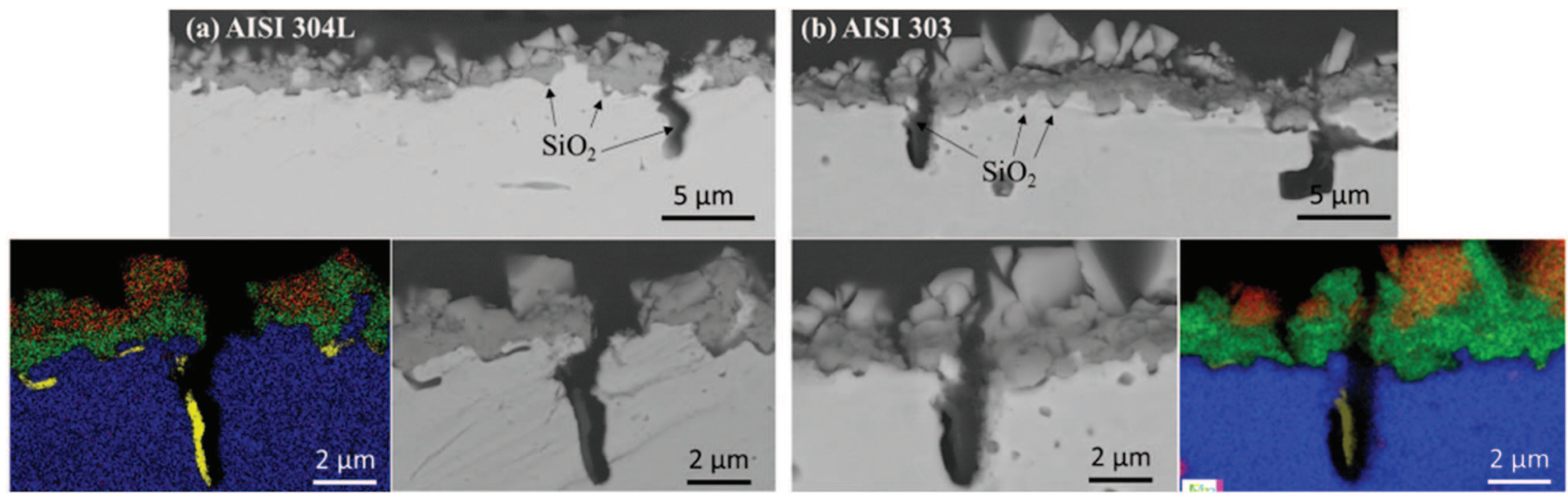

Fig. 9. SEM-BSE cross-section micrographs and EDS map after tensile testing of the oxide scale grown after oxidation at $900{ }^{\circ} \mathrm{C}$ for $50 \mathrm{~h}$ (a) on AISI $304 \mathrm{~L}$ and (b) on AISI 303 (EDS map: Cr in green, $\mathrm{Si}$ in yellow and $\mathrm{Mn}+\mathrm{Cr}$ in orange). (For interpretation of the references to colour in this figure legend, the reader is referred to the web version of this article.) 

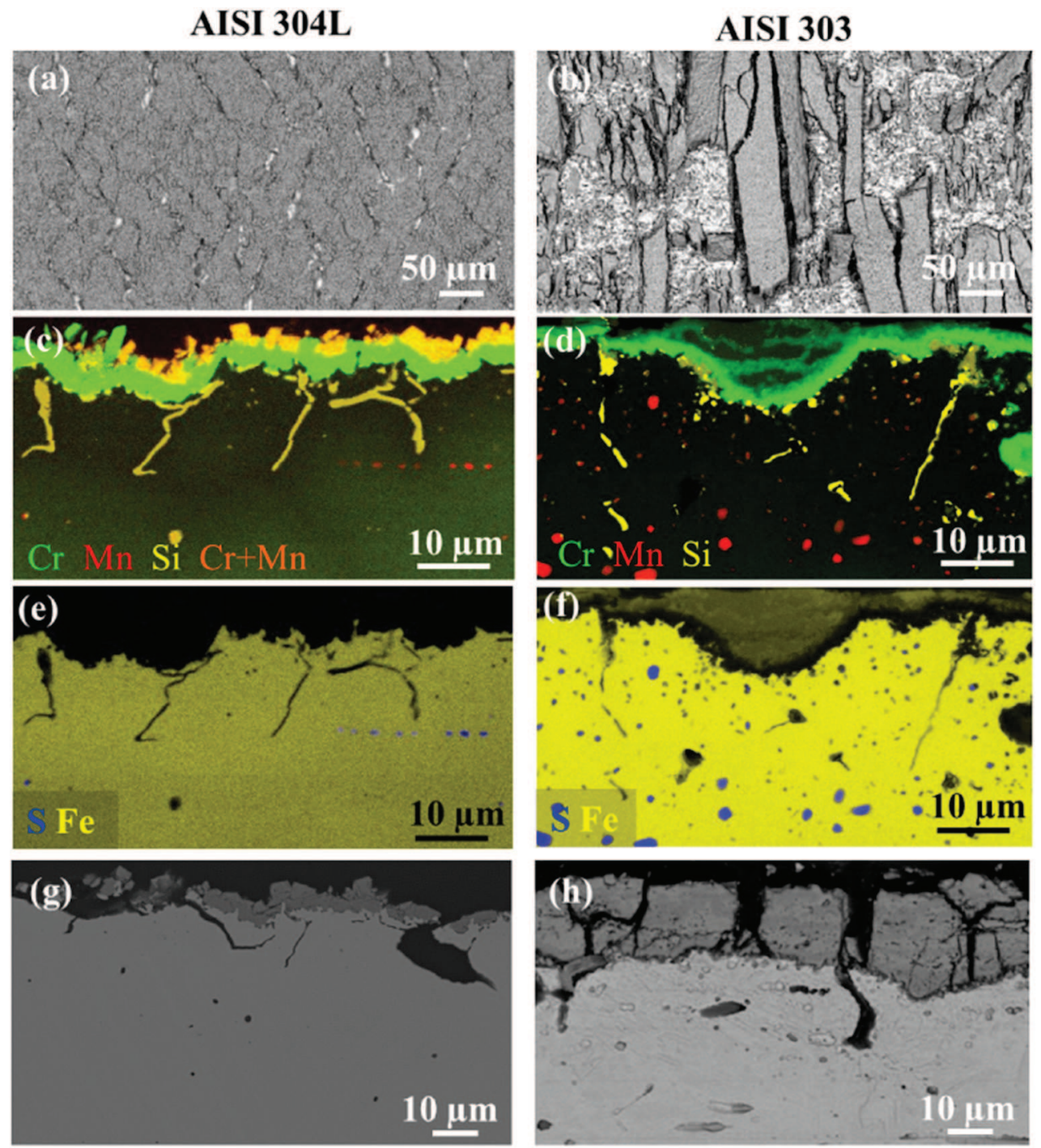

Tensile direction

Fig. 10. SEM-BSE micrographs of the oxide top surface (a) on AISI 304L and (b) on AISI 303 after tensile testing (strain 40\%), cross-section EDS maps of the oxide scale grown during oxidation at $1000{ }^{\circ} \mathrm{C}$ for $50 \mathrm{~h}$ (c, e) on AISI 304L and (d, f) on AISI 303 before tensile testing, SEM-BSE cross-section micrographs of the oxide scale grown (g) on AISI 304L and (h) on AISI 303 after tensile testing.

from EDS maps in Fig. 9, it is obvious that the cracks widening observed on the oxide surface is related to crack propagation along the grain boundaries weakened by the formation of internal silica combined with plastic deformation localization in the metal, at the root of such cracks. Therefore, at high strain level, strain is no more uniform in the metal but localized at cracks bases. Then, the strain transfer to the oxide scale is less effective. This explains the crack density saturation: at this point no new cracks can initiate since the stress level in the oxide remains too low to reach critical value [21]. Second, the internal silica along grain boundaries may also play a role in transverse crack initiation in the oxide scale.

At this point, the mechanism for oxide cracks initiation is not clear but seems related to the presence of silica inclusions along grain boundaries in the metal underneath. Moreover, results from tensile testing numerical simulations have shown that crack formation in the oxide scale is a necessary condition to break metal/inclusion interfaces [28]. Crack formation lowers the average stress in the oxide while a high stress concentration zone develops in the metal beneath the crack tip. Experimental crack patterns are well reproduced considering a silica/metal interface weaker than an oxide/metal interface [28]. In this case, after transverse cracks form in the oxide scale, decohesion of metal/silica interface occurs beneath oxide crack root, preventing oxide scale spallation. Therefore, probable scenario for damages observed in this study is (i) crack initiation in the oxide scale due to heterogeneity created by the silica at the grain boundaries in the metal, then (ii) decohesion at the metal/silica interface due to stress concentration at the oxide crack root and finally (iii) widening of the crack due to localized plastic deformation in the metal. Thus, the wavy-like cracks observed during tensile testing in Fig. 7 can be directly related to silica formed along the grain boundaries of the underlying substrate.

Transverse cracks are also initiated within the oxide scale (from internal flaws) and those cracks are more numerous in the less resistant oxide scale grown on AISI 303 (e.g. comparison of Fig. 7c and g). Moreover, AISI 303 presents a lower grain size, a higher density of grain boundaries weakened by silica and then a higher density of wavy-like cracks initiated in the substrate. These two contributions could explain the higher density of cracks at saturation observed for AISI 303 (Fig. 8a). 
These observations lead to the same conclusion as for scale grown at $700{ }^{\circ} \mathrm{C}$. The scale grown on AISI $304 \mathrm{~L}$ seems more resistant (less cracks initiated within the oxide scale) and adherent (no spallation).

\subsection{Damages in the Oxide Scales Previously Grown at $1000^{\circ} \mathrm{C}$}

After oxidation at $1000{ }^{\circ} \mathrm{C}$ for $50 \mathrm{~h}$, the cracks patterns of the oxide scale during tensile testing are strongly different for the two steels (Fig. 10). While the same behaviour as after oxidation at $900{ }^{\circ} \mathrm{C}$ is observed for AISI 304L (Figs. 7d and 10a, wavy-shaped cracks following the morphology of the alloy grain boundaries weakened by silica without spallation), transverse straight cracks perpendicular to the tensile direction appear for AISI 303 and spallation takes place (rougher and brighter areas in Fig. 10b).

These results confirm that oxide scale thermally grown on AISI 304L is more resistant and adherent to the substrate than the oxide scale grown on resulphurized AISI 303 substrate. This conclusion is in agreement with the results obtained during cyclic thermogravimetry analysis at $1000{ }^{\circ} \mathrm{C}$ for AISI $304 \mathrm{~L}$ and AISI 303 substrates [37].

To explain this difference in damage behaviour, the specimen cross-sections, before and after tensile testing, are observed (Fig. 10c-f and g-h respectively). For AISI 304L, the same oxide scale composition as after oxidation at $900{ }^{\circ} \mathrm{C}$ is observed with the intergranular silica. For AISI 303, formation of Fe-rich nodules is evidenced. Nodules microstructures have been fully described in a previous paper [36]. The external part of the nodule, partially spalled during cooling and metallographic preparation, is composed of $\mathrm{Fe}-$ rich oxides $\left(\mathrm{Fe}_{2} \mathrm{O}_{3} /(\mathrm{Fe}, \mathrm{Cr})_{2} \mathrm{O}_{3}\right)$ according to Raman spectroscopy of the oxide scale outer surface (not presented). The inner part of the nodule is composed of stratified spinel-type oxide, alternatively rich in iron, $(\mathrm{Fe}, \mathrm{Ni}, \mathrm{Cr})_{3} \mathrm{O}_{4}$, and rich in chromium, $(\mathrm{Cr}, \mathrm{Fe})_{3} \mathrm{O}_{4}$, underlined by a $\mathrm{Cr}$-rich dense layer which could be $\mathrm{Cr}_{2} \mathrm{O}_{3}$.

During oxidation at $1000{ }^{\circ} \mathrm{C}$, formation of fast growing $\mathrm{Fe}$-rich nodules is observed on AISI 303. The higher sulphur content in AISI 303 results in a higher volume fraction of MnS inclusions in the bulk than in AISI 304L. During the oxidation experiments, the increase in number and decrease in size of the sulphur containing inclusions in the underneath substrate suggest the dissociation of the MnS near the metal/oxide interface (Fig. 10d-f). Manganese diffuses to the metal/ oxide interface and is incorporated in the oxide scale whereas sulphur precipitates with other sulphide-former elements such as chromium to form $(\mathrm{Mn}, \mathrm{Cr}) \mathrm{S}$. ( $\mathrm{Mn}, \mathrm{Cr}) \mathrm{S}$ inclusions acting as oxide nucleation sites, it gives rise to oxide-sulphide aggregates (Fig. 11): ( $\mathrm{Cr}, \mathrm{Si}$ )-rich oxides and $(\mathrm{Mn}, \mathrm{Cr}$ )-rich sulphides [36].

A lower starting $\mathrm{Cr}$ value in the bulk associated to the formation of these $(\mathrm{Mn}, \mathrm{Cr}$ )-rich sulphides in the underneath substrate induce breakaway oxidation of AISI 303 at such high oxidation temperature and consequently the formation of non-protective and porous Fe-rich oxide scale [36].

The cross-section specimen after tensile testing, in Fig. 10h, shows that grain boundaries in the AISI 303 substrate also opened during the tensile testing. However, transverse cracks are mainly initiated at the level of defects within the oxide scale. Cracks growth is then easy and fast in porous oxide scale as shown in Fig. 12. Finally, spallation takes place (Fig. 12c and d). Mechanism responsible for oxide spallation is not clear but compressive stress developed perpendicularly to the loading direction due to contraction of the metal during its plastic deformation is probably the driving force.

\subsection{Relation Between Microstructure Induced by Oxidation and Oxide Scale Damages During Tensile Testing}

Three damage mechanisms are observed depending on the oxidation temperature of the tensile specimens and S content in the alloy. They are schematically summarized in Fig. 13:

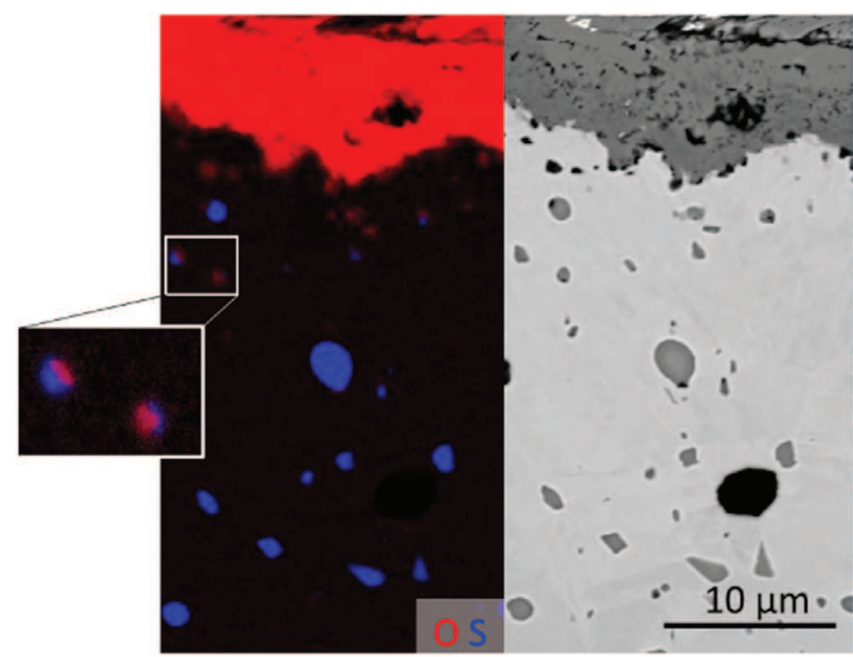

Fig. 11. Cross-section SEM micrograph and EDS maps ( $\mathrm{O}$ in red and $\mathrm{S}$ in blue) of the oxide scale grown during oxidation at $1000{ }^{\circ} \mathrm{C}$ for $50 \mathrm{~h}$ on AISI 303 before tensile testing. (For interpretation of the references to colour in this figure legend, the reader is referred to the web version of this article.)

(i) After oxidation at $700{ }^{\circ} \mathrm{C}$, the oxide scale is thin, damages start at the interface where spalling is initiated at the level of the interface weakened by silica (Fig. 13a).

(ii) After oxidation at $900{ }^{\circ} \mathrm{C}$ (and $1000{ }^{\circ} \mathrm{C}$ for low $\mathrm{S}$ grade, i.e. AISI 304L), the oxide scale is thicker, damages start mainly at heterogeneity created by intergranular silica (external initiation) (Fig. 13b).

(iii) After oxidation at $1000{ }^{\circ} \mathrm{C}$ for the high S grade (i.e. AISI 303), the oxide scale is thick and rich in Fe, damages start mainly within the oxide scale (internal initiation), cracks easily propagate in the porous Fe-rich oxide scale and severe spalling is eventually observed due to compressive stresses (Fig. 13c).

\section{Conclusions}

The spalling/cracking behaviour at room temperature of thermally grown oxide scales under tensile stress was investigated using SEM in situ tensile testing for two austenitic stainless steels with close composition except their S content: AISI 304L and AISI 303 (resulphurized steel). A correlation between damage patterns and microstructure, mechanical and adhesion properties of the oxide scale is considered.

The results obtained after oxidation at 700,900 and $1000{ }^{\circ} \mathrm{C}$ confirm that the Cr-rich thinner oxide scale thermally grown on AISI 304L steel is more protective, since it is more resistant and adherent to the substrate than the oxide scale grown on resulphurized AISI 303 substrate.

A direct effect of $\mathrm{S}$ on the oxide scale adhesion properties, reported in literature mainly for alumina-forming alloys, is not clearly evidenced. Nevertheless, the difference in oxide scale microstructure for both steels after oxidation at $1000^{\circ} \mathrm{C}$ is partly explained in relation with the volume fraction of MnS inclusions (i.e. S content) in the bulk.

The spalling/cracking behaviour is strongly affected by the oxides features: (i) oxide scale thickness, (ii) Fe content in the oxide scale and (iii) location of internal oxides $\mathrm{SiO}_{2}$ along the metal/oxide interface or along the bulk grain boundaries of the underneath substrate.

After oxidation at $700{ }^{\circ} \mathrm{C}$, spallation is favoured by high yield strength of the substrate, low thickness of the oxide scale and internal oxidation of silicon along the metal/oxide interface.

After oxidation at $900-1000{ }^{\circ} \mathrm{C}$, cracking is promoted by a softened substrate (after recovery/recrystallization annealing), a thicker oxide scale and intergranular silica within the underlying substrate. 

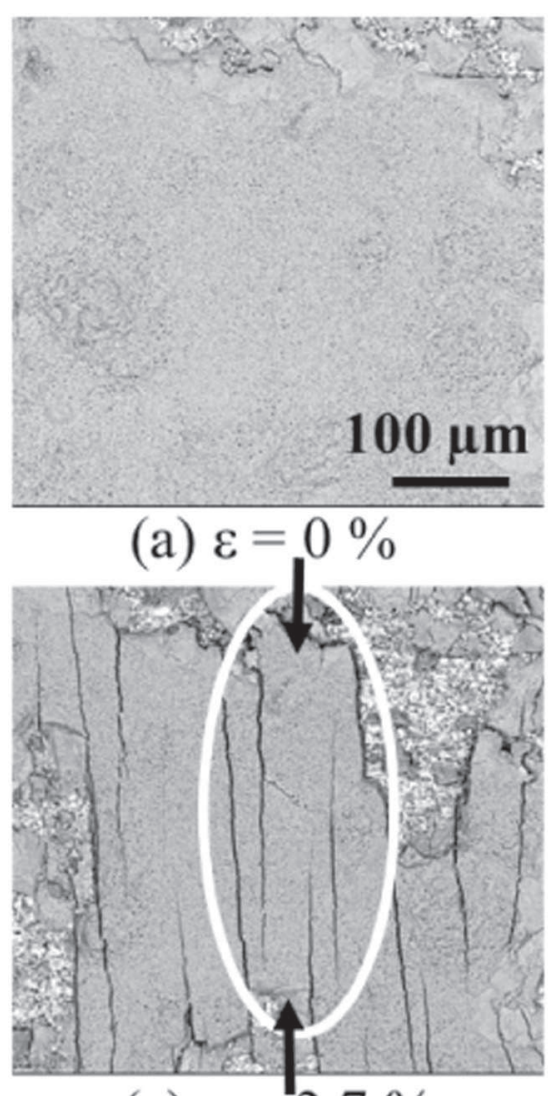

(c) $\varepsilon=3.7 \%$

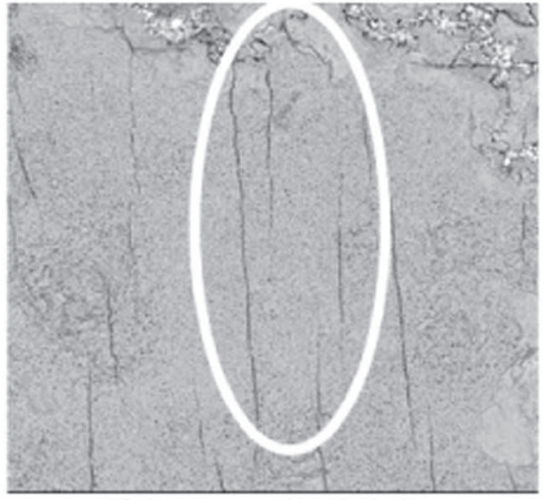

(b) $\varepsilon=0.6 \%$

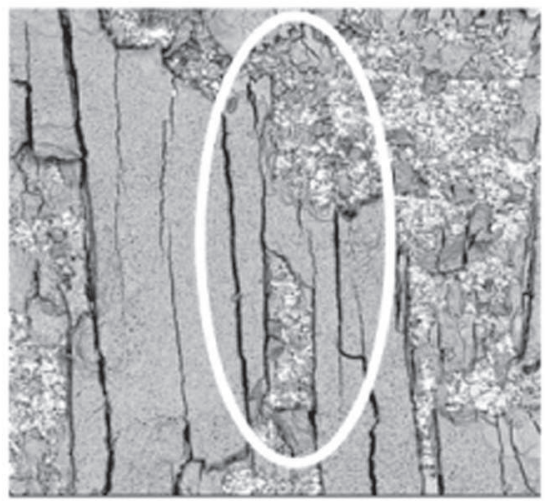

(d) $\varepsilon=10 \%$

\section{Tensile direction}

Fig. 12. Sequential SEM micrographs obtained during tensile testing of the AISI 303 specimens oxidized at $1000{ }^{\circ} \mathrm{C}$ for $50 \mathrm{~h}$ (black arrows correspond to the compressive stress).
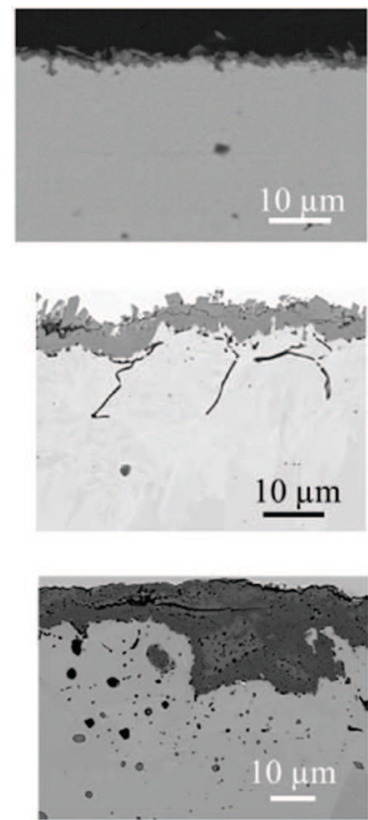

$700^{\circ} \mathrm{C} \rightarrow$ spalling: thin oxide scale

(a)

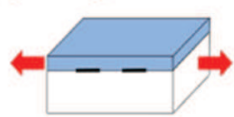

Damages start at the interface

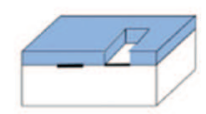

Spalling due to $\mathrm{SiO}_{2}$ discontinuous interlayer

$900^{\circ} \mathrm{C}$ and $1000{ }^{\circ} \mathrm{C}$ for low $\mathrm{S}$ grade $\rightarrow$ cracking: thicker oxide $+\mathrm{SiO}_{2}$ at $\mathrm{GB}$

(b)

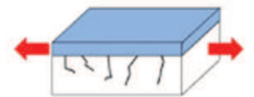

Damages start within the substrate

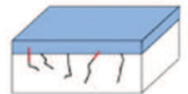

External initiation $=\mathrm{SiO}_{2}$ at $\mathrm{GB}$

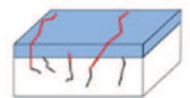

Cracks propagation

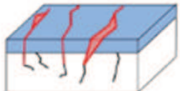

Plastic deformation at the crack base

$1000^{\circ} \mathrm{C}$ for high $\mathrm{S}$ grade $\rightarrow$ cracking and spalling: thick Fe-rich oxide

(c)

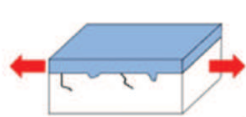

Damages start within the oxide

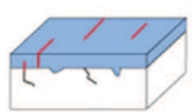

Mainly internal initiation

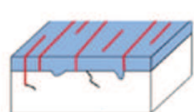

Cracks propagation

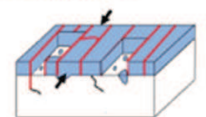

Spalling

$=$ porous Fe-rich oxide

Fig. 13. Schematic representation and corresponding cross-section SEM-BSE micrographs of the three damage mechanisms depending on oxidation temperature and S content of austenitic stainless steels. 


\section{Acknowledgments}

This work was realized in the framework of a PICS project supported by National Centre for Scientific Research (CNRS, France) Ref no. 6095 and Russian Foundation for Basic Research (RFBR) Ref no. 13-0891053-CNRS_a.

\section{References}

[1] P. Kofstad, High Temperature Corrosion, Elsevier Science Publishing Co., New York, 1988.

[2] F. Riffard, H. Buscail, E. Caudron, R. Cueff, C. Issartel, S. Perrier, Yttrium implantation effect on $304 \mathrm{~L}$ stainless steel high temperature oxidation at $1000{ }^{\circ} \mathrm{C}$, J. Mater. Sci. 37 (2002) 3925-3933.

[3] X. Peng, J. Yan, Y. Zhou, F. Wang, Effect of grain refinement on the resistance of 304 stainless steel to breakaway oxidation in wet air, Acta Mater. 53 (2005) 5079-5088.

[4] A.M. Huntz, A. Reckmann, C. Haut, C. Sévérac, M. Herbst, F.C.T. Resende, A.C.S Sabioni, Oxidation of AISI 304 and AISI 439 stainless steels, Mater. Sci. Eng. A 447 (2007) 266-276.

[5] N. Karimi, F. Riffard, F. Rabaste, S. Perrier, R. Cueff, C. Issartel, H. Buscail, Characterization of the oxides formed at $1000{ }^{\circ} \mathrm{C}$ on the AISI 304 stainless steel by X-ray diffraction and infrared spectroscopy, Appl. Surf. Sci. 254 (2008) 2292-2299.

[6] D. Lussana, D. Baldissin, M. Massazza, M. Baricco, Thermodynamic and kinetics aspects of high temperature oxidation on a 304L stainless steel, Oxid. Met. 81 (2014) 515-528.

[7] A.W. Funkenbusch, J.G. Smeggil, N.S. Bornstein, Reactive element-sulphur interaction and oxide scale adherence, Metall. Trans. A. 16A (1985) 1164-1166.

[8] J.G. Smeggil, A.W. Funkenbush, N.S. Bornstein, A relationship between indigenous impurity elements and protective oxide scale adherence characteristics, Metall. Trans. A. 17A (1986) 923-932.

[9] J.L. Smialek, Adherent $\mathrm{AI}_{2} \mathrm{O}_{3}$ scales formed on undoped NiCrAI alloys, Metall. Trans. A. 18A (1987) 164-167.

[10] J.G. Smeggil, A.J. Shuskus, N.S. Bornstein, M.A. DeCrescente, The Role of Active Elements in the Oxidation Behaviour of High Temperature Metals and Alloys, Springer, Netherlands, 1989.

[11] G. Dearnaley, The role of segregated impurities in scale adhesion, Corros. Sci. 32 (1991) 113-116.

[12] P.Y. Hou, J. Stringer, Oxide scale adhesion and impurity segregation at the scale/ metal interface, Oxid. Met. 38 (1992) 323-345.

[13] T. Gheno, D. Monceau, D. Oquab, Y. Cadoret, Characterization of sulphur distribution in Ni-based superalloy and thermal barrier coating after high temperature oxidation: a SIMS analysis, Oxid. Met. 73 (2010) 95-113.

[14] O. Li, X. Peng J.O. Zhang, G.X. Zong, F.H. Wang, Comparison of the oxidation of highsulfur Ni-25Cr-5Al alloys in as-cast and as-sputtered states, Corros. Sci. 52 (2010) 1213-1221.

[15] D.W. Yun, S.M. Seo, H.W. Jeong, Y.S. Yoo, The cyclic oxidation behaviour of Ni-based superalloy GTD-111 with sulphur impurities at $1100{ }^{\circ} \mathrm{C}$, Corros. Sci. 90 (2015) 392-401.

[16] S.N. Basu, G.J. Yurek, Effect of alloy grain size and silicon content on the oxidation of austenitic Fe-Cr-Ni-Mn-Si alloys in pure $\mathrm{O}_{2}$, Oxid. Met. 36 (1991) 281-315.
[17] H.J. Grabke, D. Wiemer, H. Viefhaus, Segregation of sulphur during growth of oxide scales, Appl. Surf. Sci. 47 (1991) 243-250.

[18] Y. Leterrier, J. Andersons, Y. Pitton, J.-A.E. Manson, Adhesion of silicon oxide layers on poly (ethylene terephthalate). II: Effect of coating thickness on adhesive and cohesive strengths, J. Polym. Sci. B Polym. Phys. 35 (9) (1997) 1463-1472.

[19] P. Scafidi, M. Ignat, Cracking and loss of adhesion of $\mathrm{Si}_{3} \mathrm{~N}_{4}$ and $\mathrm{SiO}_{2}$ : P films deposited on Al substrates, J. Adhes. Sci. Technol. 12 (1998) 1219-1242.

[20] C. Xie, W. Tong, Cracking and decohesion of a thin $\mathrm{Al}_{2} \mathrm{O}_{3}$ film on a ductile Al-5\%Mg substrate, Acta Mater. 53 (2) (2005) 477-485.

21] H. Rehman, F. Ahmed, C. Schmid, J. Schaufler, K. Durst, Study on the deformation mechanics of hard brittle coatings on ductile substrates using in situ tensile testing and cohesive zone FEM modeling, Surf. Coat. Technol. 207 (2012) 163-169.

[22] M.M. Nagl, W.T. Evans, D.J. Hall, S.R.J. Saunders, An in situ investigation of the tensile failure of oxide scales, Oxid. Met. 42 (5-6) (1994) 431-449.

[23] S. Perusin, B. Viguier, J.C. Salabura, D. Oquad, E. Andrieu, Behaviour of the oxide scale during SEM in situ plastic deformation of pure nickel foil, Mater. Sci. Eng. A 387-389 (2004) 763-767.

[24] S. Chandra-Ambhorn, F. Roussel-Dherbey, F. Toscan, Y. Wouters, A. Galerie, M. Dupeux, Determination of mechanical adhesion energy of thermal oxide scales on AISI 430Ti alloy using tensile test, Mater. Sci. Technol. 23 (4) (2007) 497-501.

[25] H.E. Evans, Stress effects in high temperature oxidation of metals, Int. Mater. Rev. 40 (1) (1995) $1-40$.

26] B.F. Chen, J. Hwang, I.F. Chen, G.P. Yu, J.H. Huang, A tensile film cracking model for evaluating interfacial shear strength of elastic film on ductile substrate, Surf. Coat. Technol. 126 (2000) 91-95.

[27] M.D. Thouless, Cracking and delamination of coatings, J. Vac. Sci. Technol. A 9 (1991) 2510.

[28] V. Parry, C. Pascal, M. Braccini, E. Fedorova, M. Mantel, Y. Wouters, D. Oquab, D. Monceau, R. Estevez, G. Parry, Relations between oxidation induced microstructure and mechanical durability of oxide scales, Oxid. Met. (2016), http://dx.doi.org/10 1007/s11085-016-9673-5.

[29] Datasheet on http://www.northamericanstainless.com

30] G. Bamba, Y. Wouters, A. Galerie, F. Charlot, A. Dellali, Thermal oxidation kinetics and oxide scale adhesion of $\mathrm{Fe}-15 \mathrm{Cr}$ alloys as a function of their silicon content, Acta Mater. 54 (2006) 3917-3922.

[31] A.F. Padhila, R.L. Plaut, P.R. Rios, Review annealing of cold-worked austenitic stainless steels, ISIJ Int. 43 (2) (2003) 135-143.

[32] M. Shirdel, H. Mirzadeh, M.H. Parsa, Abnormal grain growth in AISI 304L stainless steel, Mater. Charact. 97 (2014) 11-17.

[33] D.J. Young, High Temperature Oxidation and Corrosion of Metals, Elsevier, 2008.

[34] G.J. Yurek, D. Eisen, A. Garrat-Reed, Oxidation behavior of a fine-grained rapidly solidified 18-8 stainless steel, Metall. Trans. A. 13A (1982) 473-485.

[35] F. Toscan, PhD thesis, Institut National Polytechnique de Grenoble, 2004.

[36] C. Pascal, V. Parry, E. Fedorova, M. Braccini, P. Chemelle, N. Meyer, D. Oquab, D. Monceau, Y. Wouters, M. Mantel, Breakaway oxidation of austenitic stainless steels induced by alloyed sulphur, Corros. Sci. 93 (2015) 100-108.

[37] E. Fedorova, M. Braccini, V. Parry, C. Pascal, M. Mantel, F. Roussel-Dherbey, D. Oquab, Y. Wouters, D. Monceau, Comparison of damaging behavior of oxide scales grown on two austenitic stainless steels using tensile test and cyclic thermogravimetry, Corros. Sci. 103 (2016) 145-156. 